The Review of Finance and Banking

print ISSN 2067-2713, online ISSN 2067-3825

Volume 12, Issue 1, Year 2020

http://dx.doi.org/10.24818/rfb.20.12.01.03, Pages 31-47

\title{
LIQUIDITY RISK MANAGEMENT OF AFFILIATED BANKS DURING THE SUB-PRIME MORTGAGE CRISIS
}

\author{
NILUFER OZDEMIR
}

\begin{abstract}
A majority of commercial banks in the U.S. are affiliated with a bank holding company. They rely on their internal capital markets for satisfying daily liquidity needs. Did these internal capital markets actually help affiliates during the sub-prime mortgage crisis? By implementing the difference-in-difference technique, this paper measures the role of internal markets. Results show that flows between parent institutions and banks, as well as flows among banks affiliated with the same parent were not effective in preventing a decline in lending during the crisis. On the other hand, banks that had access to non-bank affiliate funds continued to lend.
\end{abstract}

\section{INTRODUCTION}

Most commercial banks in the U.S. are affiliated with a bank holding company -BHC hereafter. Affiliated banks are known to rely on their internal capital markets because of the high cost of external financing. Stein (1997) shows that BHCs shuffle funds among their affiliates and help these banks continue to lend even during difficult times. On the other hand, banks deprived of these internal funds suffer most when liquidity is tight.

Did the internal flow of funds help affiliated banks during the financial market turmoil in 2007 and 2008? An extensive literature has grown following the 2007-2008 crisis to analyze the impact of this crisis. However, research in this area has typically disregarded the role of internal capital markets (Antoniades (2014)). One major reason for the lack of studies in this area is that the data on inter-company flows of US banks are confidential. Previous studies in this area have either ignored the role of internal flows by treating affiliated and unaffiliated banks similarly (Cole and White (2012) and Cornett et al. (2011)) or they have used proxies to estimate the impact of internal markets (Houston, James and Marcus (1997)).

Affiliated and unaffiliated banks differ in terms of the internal flows of funds to which they have access and the impact of this merits investigation. Furthermore, there is a difference in the types of internal flows as well: parent-to-affiliate flows may function differently than affiliateto-affiliate flows. This paper extends the literature by applying difference-in-difference analysis to evaluate the role of internal capital markets on banks' liquidity management decisions. By suggesting a difference-in-difference analysis, DD hereafter, the paper compares banks that are different in terms of their affiliation status and therefore, the types of internal flows they have access to. Each time DD is implemented, one new flow is introduced, which makes it possible to study the impact of that particular flow on banks' liquidity management.

The question analyzed in this paper is essential in terms of evaluating the risks and benefits of BHC affiliation in financial markets. While previous literature has established that internal

Received by the editors August 21, 2019. Accepted by the editors May 26, 2020.

Keywords: Financial markets, Financial crises, Banks, Bank Holding Companies, Internal capital markets, Liquidity management.

JEL Classification: G01, G11, G17, G21.

Nilufer Ozdemir, PhD, Assistant Professor, Coggin College of Business, University of North Florida, Jacksonville, Florida, USA. E-mail: n.ozdemir@unf.edu.

This paper is in final form and no version of it will be submitted for publication elsewhere. 
markets are important, they did not examine what kind of internal markets are more beneficial for financial markets. This study investigates the role of different internal flows to address this. Second, the method employed in the paper allows crisis and non-crisis periods to be evaluated separately. This is particularly important for policymakers since the findings of the paper indicate that policymakers face a trade-off: They could either encourage financial flows that can result in uninterrupted credit flows during the crisis period or encourage financial flows that support faster credit flows during the non-crisis period. The findings of the paper help policymakers by providing evidence on the differential impact of internal flows in affiliated banks.

\section{Literature Review}

This paper is closely related to the literature analyzing the influence of liquidity shocks on banks' credit supply - namely credit channel of monetary policy. Campello (2002) is one of the leading examples of this literature. He analyzes the workings of the credit channel for affiliated banks and finds that internal capital markets relax the credit constraints faced by bank affiliates. This lessens the impact of the Fed policies on bank lending activity. In their frequently cited article, Houston, James and Marcus (1997) show that multibank BHCs use internal capital markets to distribute both capital and liquidity to bank subsidiaries. They find that affiliated banks' lending is more sensitive to BHC cash flows than banks' own cash flows. Similarly, Houston and James (1998) find that standalone banks are more dependent on their own funds than holding company affiliates are on theirs.

Recent articles in this literature focus on the liquidity shock associated with the subprime mortgage crisis. Cornett et al. (2011) analyze banks' response to the recent crisis by combining figures from both standalone banks and affiliated banks together. They find that banks relying more heavily on core deposits and capital for financing were able to continue lending, unlike other banks during the crisis. Another related study is Bianchi and Bigio (2017). They discuss the impact of disruptions in the interbank market on the decline in lending and liquidity hoarding by banks during the 2007-2008 financial crisis. However, they do not specifically analyze the role of internal capital markets.

Correa, Goldberg and Rice (2014) look at the liquidity management of multi-company banks during this crisis. However, they only analyze banks with international connections. They find that large U.S. global banks, which tend to borrow more from affiliates also have more stable domestic lending and credit growth as liquidity risk conditions worsen. Once again, they do not separate the effect of internal capital markets on these banks. Another study that focuses on only international bank flows is Ceterolli and Goldberg (2012). They document the funds that regularly flow between parent banks and their affiliates in diverse foreign markets. Their findings indicate that affiliate locations that are important for the parent bank revenue streams are relatively protected from liquidity reallocations in the organization. In contrast, traditional funding locations are more extensively used to buffer shocks to the parent bank balance sheets.

Matvos and Seru (2014) extend this literature by looking at the impact of fund transfers between different industries. They demonstrate that conglomerates shift resources between industries in response to shocks to the financial sector. However, Matvos and Seru (2014) do not report any findings regarding the lending behavior of banks. This paper extends their analysis by analyzing the role of flows on banks' liquidity management.

The next section will begin with the description of the data. Section 4 reports our main results. Robustness checks are discussed in Section 5. Section 6 concludes.

\section{DATA}

The study combines the commercial bank data that come from the Fed's Call Reports with the BHC figures, which are downloaded from FR Y-9LP and 9SP reports. Call Reports contain detailed balance sheet information for all banks. These reports can be downloaded from the 
Fed Chicago's website. In this study, we collect information on bank assets, deposits, capital, undrawn loan commitments and affiliation status from these reports. The FR Y-9LP and 9SP reports collect basic financial data from BHCs. We download the information on the number of affiliates and the nature of bank affiliates - whether they are banks or nonbanks - from these reports. The data are quarterly and cover the period between 2006Q1 and 2009Q2.

Since the paper focuses on the role of internal flows in dealing with the subprime mortgage crisis, the analysis excludes the following banks that are not appropriate for this analysis:

1) Banks that have only pre-crisis or only crisis observations,

2) Banks that merged during this paper's period,

3) Banks that have global connections,

4) Banks whose affiliation status changed in this paper's time period. For instance, we exclude banks that were stand-alone banks initially and became affiliated later ${ }^{1}$.
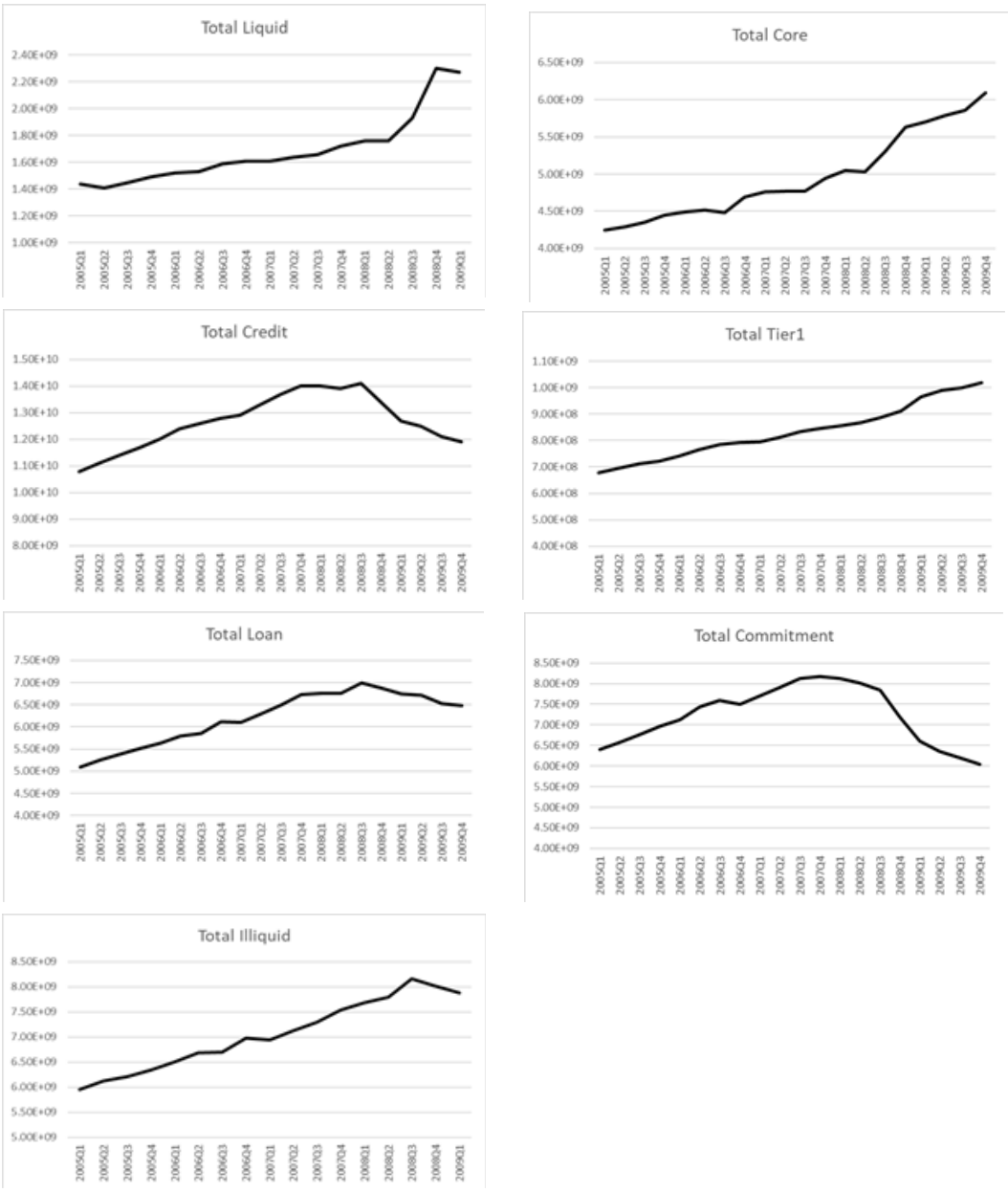

Figure1: Graphical Representation of the Liquidity Management Indicators

Cornett et al. (2011) and Correa, Goldberg and Rice (2014) use three indicators in analyzing the banks' liquidity management behavior: credit growth, loan growth ${ }^{2}$ and liquid asset growth. They demonstrate that, among other things, liquidity management of banks depends on the

\footnotetext{
${ }^{1}$ After these exclusions, the sample includes 3,353 banks.

${ }^{2}$ Credit is equal to the sum of loans on the balance sheet plus undrawn loan commitments off the balance sheet.
} 
structure of the bank balance sheet. They use four indicators: core deposit, tier 1 capital, illiquid assets and bank commitments to represent this structure. We will mostly follow their approach in our analysis below but also introduce the role of internal capital markets in the liquidity management.

Figure 1 shows the liquidity management indicators that Cornett et al. (2011) and Correa at al. (2014) use. In this figure, Total Liquid, Total Credit, Total Loan, Total Illiquid, Total Core, Total Tier 1 and Total Commitment are the aggregate figures. Each data point in the graphs represents the value of a particular variable that is summed over individual bank values for each quarter. The reader can find more detailed descriptions of the variables in Appendix A.

All seven graphs in Figure 1 reveal a shift toward a more cautious bank management strategy during the crisis as compared to the pre-crisis period. The change in the asset management approach can be seen especially in the liquid asset holdings. Starting from 2008Q2, liquid asset holdings seem to increase sharply while banks cut back on their illiquid asset holdings. In addition to the decline in the size of the loan and credit portfolio, the commitments peak at around early 2008Q1 and decline significantly afterward.

The graphs also depict a switch toward more careful liability management during the crisis period. We observe an increase in banks' reliance on more secure resources to finance their activities such as core deposit and Tier 1 capital. Overall, the graphs in Figure 1 represent a structural change in banks' management strategy during the crisis period, which merits further analysis.

The types of internal flows that can take place in internal capital markets depend on two factors: the number of affiliates and the type of affiliates. For example, the dynamics of the funding mechanisms are different for a bank owned by a holding company with no other affiliate banks and a bank owned by a holding company that has multiple affiliates, some of which are not banks. To properly study the differences between holding company structures and its impact on lending, the paper introduces a new categorization of banks and classifies banks into the following groups: Stand-alone banks, OBHC-banks, OBHC-nonbanks, MBHC-banks, MBHCnonbanks. The first letter designates whether the bank belongs to a group that holds one (O) or multiple (M) banks ${ }^{3}$. The second part of the designation shows if there are non-bank affiliates in the group. Therefore, if the group holds only one bank affiliate, then the affiliated bank is called an OBHC-bank. If the group holds more than one bank affiliate, then each affiliated bank is named an MBHC-bank. Finally, if the group includes more than one bank affiliate and also non-bank affiliates, each affiliated bank is called a MBHC-non-bank. The details of the bank classification can be found in Appendix B.

Table Ia and Ib present the basic characteristics of these bank groups ${ }^{4}$. In these tables, the reader can find the mean, 25th, 50th and 75th percentile values and the standard errors respectively. Each row in these two tables shows the change in a particular variable, for instance, the change in loans. Table Ia shows that banks in these groups have different characteristics in the pre-crisis period. The OBHC-banks and the OBHC-nonbanks had faster growth in their credit portfolios. They both invested in illiquid assets more than other banks. The MBHCbanks and the MBHC-nonbanks had higher illiquid asset growth than the stand-alone banks. Among these bank groups, the MBHC-nonbanks are the ones that had the lowest core-deposit growth compared to others. In terms of the capital ratios, the stand-alone banks had the fastest capital growth followed by the MBHC-affiliated banks. The last significant difference between the banks in the sample appears to be in their commitments. The OBHC-banks and the OBHC-nonbanks had the highest commitment change indicating that they were exposed to high liquidity risk in the pre-crisis period. Moreover, the MBHC-banks and the MBHC-nonbanks both have higher commitment growth than stand-alone banks.

\footnotetext{
${ }^{3} \mathrm{OBHC}$ and $\mathrm{MBHC}$ are a one-bank holding company and multi-bank holding company respectively.

${ }^{4}$ In these tables and the following tables, $\Delta$ represents the growth of a particular variable.
} 


\begin{tabular}{|c|c|c|c|c|c|}
\hline & Mean & $\mathrm{p} 25$ & $\mathrm{p} 50$ & p75 & $\mathrm{Sd}$ \\
\hline \multicolumn{6}{|l|}{ Stand-alone } \\
\hline$\Delta$ Liquid & -0.01 & -0.03 & 0.00 & 0.02 & 0.05 \\
\hline$\Delta$ Loan & 0.01 & 0.00 & 0.01 & 0.03 & 0.04 \\
\hline$\Delta$ Credit & 0.04 & -0.02 & 0.02 & 0.10 & 0.64 \\
\hline$\Delta$ Illiquid & 0.66 & 0.57 & 0.71 & 0.81 & 0.20 \\
\hline$\Delta$ Core & 0.63 & 0.58 & 0.66 & 0.73 & 0.16 \\
\hline$\Delta$ Tier1 & 0.15 & 0.09 & 0.11 & 0.15 & 0.12 \\
\hline$\Delta$ Commitment & 0.36 & 0.07 & 0.28 & 0.59 & 0.31 \\
\hline \multicolumn{6}{|l|}{ OBHC-bank } \\
\hline$\Delta$ Liquid & 0.00 & -0.01 & 0.00 & 0.01 & 0.03 \\
\hline$\Delta$ Loan & 0.01 & 0.00 & 0.01 & 0.03 & 0.03 \\
\hline$\Delta$ Credit & 0.07 & -0.04 & 0.06 & 0.17 & 0.33 \\
\hline$\Delta$ Illiquid & 0.78 & 0.73 & 0.79 & 0.84 & 0.09 \\
\hline$\Delta$ Core & 0.64 & 0.58 & 0.64 & 0.71 & 0.10 \\
\hline$\Delta$ Tier1 & 0.09 & 0.08 & 0.09 & 0.09 & 0.02 \\
\hline$\Delta$ Commitment & 0.84 & 0.80 & 0.86 & 0.92 & 0.11 \\
\hline \multicolumn{6}{|l|}{ MBHC-bank } \\
\hline$\Delta$ Liquid & 0.00 & -0.02 & 0.00 & 0.02 & 0.04 \\
\hline$\Delta$ Loan & 0.01 & -0.01 & 0.01 & 0.02 & 0.04 \\
\hline$\Delta$ Credit & 0.04 & -0.05 & 0.03 & 0.12 & 0.22 \\
\hline$\Delta$ Illiquid & 0.73 & 0.68 & 0.76 & 0.83 & 0.15 \\
\hline$\Delta$ Core & 0.64 & 0.59 & 0.66 & 0.72 & 0.14 \\
\hline$\Delta$ Tier1 & 0.10 & 0.08 & 0.09 & 0.10 & 0.10 \\
\hline$\Delta$ Commitment & 0.57 & 0.38 & 0.58 & 0.79 & 0.26 \\
\hline \multicolumn{6}{|l|}{ OBHC-nonbank } \\
\hline$\Delta$ Liquid & 0.00 & -0.01 & 0.00 & 0.01 & 0.03 \\
\hline$\Delta$ Loan & 0.01 & 0.00 & 0.01 & 0.02 & 0.02 \\
\hline$\Delta$ Credit & 0.06 & -0.05 & 0.05 & 0.15 & 0.27 \\
\hline$\Delta$ Illiquid & 0.79 & 0.75 & 0.80 & 0.85 & 0.09 \\
\hline$\Delta$ Core & 0.62 & 0.58 & 0.64 & 0.70 & 0.11 \\
\hline$\Delta$ Tier1 & 0.09 & 0.08 & 0.08 & 0.09 & 0.02 \\
\hline$\Delta$ Commitment & 0.87 & 0.83 & 0.90 & 0.95 & 0.12 \\
\hline \multicolumn{6}{|l|}{ MBHC-nonbank } \\
\hline$\Delta$ Liquid & -0.01 & -0.02 & 0.00 & 0.01 & 0.05 \\
\hline$\Delta$ Loan & 0.01 & -0.01 & 0.01 & 0.02 & 0.04 \\
\hline$\Delta$ Credit & -0.03 & -0.05 & 0.02 & 0.11 & 5.14 \\
\hline$\Delta$ Illiquid & 0.71 & 0.67 & 0.77 & 0.84 & 0.22 \\
\hline$\Delta$ Core & 0.58 & 0.54 & 0.63 & 0.71 & 0.21 \\
\hline$\Delta$ Tier1 & 0.13 & 0.07 & 0.08 & 0.10 & 0.18 \\
\hline$\Delta$ Commitment & 0.64 & 0.45 & 0.70 & 0.91 & 0.30 \\
\hline
\end{tabular}

Overall, this table shows that the stand-alone banks had safer balance sheets in the pre-crisis period. Both the OBHC-banks and the OBHC-nonbanks made brave choices and this increased their exposure to liquidity and solvency risk.

Table Ib shows the crisis period choices. All of the banks in the sample are seen to have slowed down their credit growth. The share of illiquid assets and core deposits either stayed the same or increased slightly. The tier1 capital of the MBHC-bank and the MBHC-nonbanks 
increased slightly, while this ratio went down somewhat for the OBHC-nonbanks. Both the MBHC-banks and the MBHC-nonbanks had lower commitments increases in this period.

\begin{tabular}{|c|c|c|c|c|c|}
\hline & Mean & $\mathrm{p} 25$ & p50 & p75 & $\mathrm{Sd}$ \\
\hline \multicolumn{6}{|l|}{ Stand-alone } \\
\hline$\Delta$ Liquid & \begin{tabular}{|l|}
-0.01 \\
\end{tabular} & -0.03 & 0.00 & 0.02 & 0.05 \\
\hline$\Delta$ Loan & 0.01 & -0.01 & 0.01 & 0.03 & 0.04 \\
\hline$\Delta$ Credit & 0.03 & -0.02 & 0.02 & 0.10 & 0.77 \\
\hline$\Delta$ Illiquid & 0.68 & 0.60 & 0.73 & 0.82 & 0.20 \\
\hline$\Delta$ Core & 0.62 & 0.56 & 0.65 & 0.72 & 0.16 \\
\hline$\Delta$ Tier1 & 0.15 & 0.09 & 0.11 & 0.15 & 0.12 \\
\hline$\Delta$ Commitment & 0.36 & 0.07 & 0.29 & 0.59 & 0.31 \\
\hline \multicolumn{6}{|l|}{ OBHC-bank } \\
\hline$\Delta$ Liquid & 0.00 & $\begin{array}{l}-0.02 \\
\end{array}$ & 0.00 & 0.01 & 0.03 \\
\hline$\Delta$ Loan & 0.01 & 0.00 & 0.01 & 0.02 & 0.02 \\
\hline$\Delta$ Credit & 0.03 & -0.07 & 0.03 & 0.14 & 0.26 \\
\hline$\Delta$ Illiquid & 0.79 & 0.75 & 0.81 & 0.85 & 0.09 \\
\hline$\Delta$ Core & 0.63 & 0.58 & 0.64 & 0.70 & 0.10 \\
\hline$\Delta$ Tier1 & 0.09 & 0.08 & 0.08 & 0.09 & 0.02 \\
\hline$\Delta$ Commitment & 0.84 & 0.80 & 0.86 & 0.92 & 0.11 \\
\hline \multicolumn{6}{|l|}{ MBHC-bank } \\
\hline$\Delta$ Liquid & 0.00 & $\begin{array}{c}-0.02 \\
\end{array}$ & 0.00 & 0.02 & 0.04 \\
\hline$\Delta$ Loan & 0.00 & -0.01 & 0.00 & 0.02 & 0.04 \\
\hline$\Delta$ Credit & 0.00 & -0.08 & 0.00 & 0.10 & 0.22 \\
\hline$\Delta$ Illiquid & 0.73 & 0.68 & 0.76 & 0.84 & 0.16 \\
\hline$\Delta$ Core & 0.63 & 0.57 & 0.66 & 0.72 & 0.14 \\
\hline$\Delta$ Tier1 & 0.11 & 0.08 & 0.09 & 0.10 & 0.11 \\
\hline$\Delta$ Commitment & 0.55 & 0.36 & 0.56 & 0.77 & 0.26 \\
\hline \multicolumn{6}{|l|}{ OBHC-nonbank } \\
\hline$\Delta$ Liquid & 0.00 & -0.01 & 0.00 & 0.01 & 0.03 \\
\hline$\Delta$ Loan & 0.01 & -0.01 & 0.01 & 0.02 & 0.03 \\
\hline$\Delta$ Credit & 0.01 & -0.09 & 0.02 & 0.12 & 0.25 \\
\hline$\Delta$ Illiquid & 0.80 & 0.76 & 0.81 & 0.85 & 0.08 \\
\hline$\Delta$ Core & 0.62 & 0.57 & 0.64 & 0.69 & 0.10 \\
\hline$\Delta$ Tier1 & 0.08 & 0.07 & 0.08 & 0.09 & 0.02 \\
\hline$\Delta$ Commitment & 0.87 & 0.82 & 0.90 & 0.95 & 0.12 \\
\hline \multicolumn{6}{|c|}{ MBHC-nonbank } \\
\hline$\Delta$ Liquid & 0.00 & -0.02 & 0.00 & 0.02 & 0.05 \\
\hline$\Delta$ Loan & 0.01 & -0.01 & 0.00 & 0.02 & 0.04 \\
\hline$\Delta$ Credit & \begin{tabular}{|l|}
-0.09 \\
\end{tabular} & -0.07 & 0.00 & 0.10 & 4.98 \\
\hline$\Delta$ Illiquid & 0.71 & 0.68 & 0.78 & 0.85 & 0.23 \\
\hline$\Delta$ Core & 0.57 & 0.53 & 0.63 & 0.70 & 0.22 \\
\hline$\Delta$ Tier1 & 0.14 & 0.07 & 0.08 & 0.10 & 0.19 \\
\hline$\Delta$ Commitment & 0.63 & 0.43 & 0.69 & 0.91 & 0.31 \\
\hline
\end{tabular}

\section{Methodology: Difference-in-Difference Estimations}

DD is a quasi-experimental design that obtains the effect of a specific change, which is called treatment, by comparing the changes in outcomes over time between two groups. This comparison eliminates the differences in the outcomes that come from either permanent differences or 
a third factor, such as the trend effect (See Wooldridge (2010) for details). One of the leading examples of this literature is Card and Krueger (1994). Card and Krueger (1994) compare employment in the fast-food sector in New Jersey and Pennsylvania, after minimum wage rose from $\$ 4.25$ to $\$ 5.05$. Butler and Cornaggia (2008) use ethanol mandates from the Environmental Protection Agency to analyze the effect of access to finance on farmers' productivity.

The studies using DD can also be found in banking literature. Adams-Kane, Caballero and Lim (2016) investigate whether the credit supply of foreign-owned financial institutions differs systematically while their home economies are experiencing a crisis. Chava and Purnanandam (2010) study the effect of the Russian crisis of 1998 on demand for bank loans and banks' credit supply.

This section implements the DD method to the affiliated banks' liquidity management during the subprime mortgage crisis.

$$
\Delta Y_{i t}=T_{1 t}+B_{1 i}+\beta_{1}^{\prime} B H C_{i}+\beta_{2}^{\prime} B H C_{i} * \text { Crisis }+\beta_{3} X_{i, t-1}+\beta_{4}^{\prime} X_{i, t-1} * \text { Crisis }+\varepsilon_{i t t}
$$

Equation (1) is adopted from Cornett et al. (2011)'s model. $\Delta Y_{i t}$ represents one of the three variables: change in liquid assets/total assets, change in credits/total assets and change in loans/total assets. $T 1$ is time effects. $B_{1}$ is $B H C$-level fixed effects. $X$ is a vector of control variables that captures the degree to which the bank is exposed to the liquidity risk. $X$ includes variables such as illiquid assets/ total assets, core deposits/ total assets, capital/ total assets and commitment/commitments+ total assets. Crisis is a dummy variable that takes the value of 1 between the last quarter of 2007 and the middle of 2009 and 0 otherwise.

The paper modifies Cornett et al. (2011)'s model by introducing $B H C$ affiliation. $B H C$ in Equation (1) is a dummy variable that defines the affiliation status of the banks included in the regressions. This affiliation indicator is replaced by $O B H C, M B H C$ or $M B H C N B$ in Equations (2), (3) and (4) below. $O B H C, M B H C B$ and $M B H C$-nonbanks are the dummy variables that will take the value of 1 if the bank is affiliated with a one-bank holding company, a multi-bank holding company or a multi-bank holding company with non-bank affiliates respectively.

Three different versions of Equation (1) below are estimated for the 2006Q1 to 2009Q2 period. Each time the equation is estimated, only two groups of banks are included in the regressions. These groups differ from one another according to the availability of various internal flows (as illustrated in Figure 3a, 3b and 3c of Appendix $\mathrm{B}^{5}$ ). As a result, the dummy variable in a specific equation measures the role of the new flow on banks' liquidity management.

The Role of Parent/Bank Flows: OBHC-Banks versus Stand-Alone Banks

$$
\Delta Y_{i t}=T_{1 t}+B_{1 i}+\beta_{1}^{\prime} O B H C_{i}+\beta_{2}^{\prime} O B H C_{, i} * \text { Crisis }+\beta_{3} X_{i, t-1}+\beta_{4}^{\prime} X_{i, t-1} * \text { Crisis }+\varepsilon_{i t t}
$$

Equation (2) is estimated for a sample that includes only the stand-alone banks and the OBHC-banks. No internal flows are available to the stand-alone banks. Only one type of internal flow is available to the group with only one bank affiliate: the parent/bank flow. Therefore, $\beta_{1}$ and $\beta_{2}$ in this equation show the impact of the parent/bank flows on banks' liquidity management.

\footnotetext{
${ }^{5}$ Appendix B also describes the parent/bank flows, bank/bank flows and bank/non-bank flows.
} 


\begin{tabular}{|c|c|c|c|c|c|c|}
\hline \multicolumn{7}{|c|}{ Table II: Parent/Bank Flows of Stand-Alone Banks versus OBHC-Banks } \\
\hline & $\Delta$ Credit & & $\Delta$ Loan & & $\Delta$ Liquid & \\
\hline & Coef. & Std. err & Coef. & Std. err & Coef. & Std. err \\
\hline $\mathrm{C}$ & $-0.026^{* * *}$ & 0.006 & -0.001 & 0.002 & 0.000 & 0.001 \\
\hline OBHC-bank & $0.944^{* * *}$ & 0.165 & $0.132^{* *}$ & 0.055 & $0.045^{* *}$ & 0.018 \\
\hline OBHC-bank*Crisis & $-0.043^{* * *}$ & 0.009 & $-0.003^{* * *}$ & 0.001 & -0.001 & 0.002 \\
\hline Illiquid & $-0.117 * * *$ & 0.039 & $-0.066^{* * *}$ & 0.011 & $0.246^{* * *}$ & 0.015 \\
\hline Illiquid ${ }^{*}$ Crisis & $-0.052^{* * *}$ & 0.013 & $-0.010 * * *$ & 0.003 & $0.013^{* * *}$ & 0.005 \\
\hline Core & $-0.172^{* * *}$ & 0.064 & 0.009 & 0.013 & $-0.026^{* * *}$ & 0.010 \\
\hline Core $^{*}$ Crisis & $0.094^{* * *}$ & 0.024 & 0.005 & 0.003 & 0.000 & 0.005 \\
\hline Tier1 & -0.095 & 0.103 & $0.074^{* * *}$ & 0.024 & 0.014 & 0.028 \\
\hline Tier1 $^{*}$ Crisis & $0.087^{* * *}$ & 0.032 & 0.004 & 0.005 & 0.020 & 0.013 \\
\hline Commitment & $-0.289^{* * *}$ & 0.059 & $0.091^{* * *}$ & 0.009 & $-0.051^{* * *}$ & 0.009 \\
\hline Commitment* Crisis & 0.001 & 0.014 & 0.000 & 0.002 & $0.005^{*}$ & 0.003 \\
\hline Logta & $-0.101^{* * *}$ & 0.035 & $-0.032^{* * *}$ & 0.011 & $-0.033^{* * *}$ & 0.004 \\
\hline Logta* $^{*}$ Crisis & -0.002 & 0.002 & $0.000^{*}$ & 0.000 & -0.001 & 0.001 \\
\hline Obs & 22100 & & 22100 & & 20550 & \\
\hline $\mathrm{R}^{\wedge} 2$ & 0.07 & & 0.10 & & 0.12 & \\
\hline
\end{tabular}

The results in Table II show that the signs of the control variables in the regressions are in line with Cornett et al. (2011)'s and the literature's findings. The coefficients of the illiquid assets show that the banks that held more illiquid assets decreased their lending more during the financial crisis and increased their liquid asset holdings as in Cai and Zhang (2017). In line with Berrospide (2013)'s findings, the banks relying on higher core deposit and Tier1 capital were able to make more loans during the crisis.

The coefficients of $O B H C$-bank and $O B H C$-bank $* C r i s i s$ are both found to be significant. The $O B H C$-banks, in general, had a faster loan and credit growth compared to the standalone banks. Their high level of liquidity fits Ashcraft, McAndrews and Skeie (2011)'s model that discusses banks' precautionary liquidity hoarding against liquidity shocks. However, when the crisis hit, the $O B H C$-banks decreased their loans more than the stand-alone banks. This finding is in line with Ashcraft (2008) who demonstrates a similar effect for flows in internal capital markets of affiliated banks. These flows caused banks to have faster loan growth in the pre-crisis period. But, as in Campello (2002), affiliated banks had to correct their balance sheets faster than the stand-alone ones during the crisis period.

The Role of Bank/Bank Flows: $O B H C$-Banks versus $M B H C$-Banks

Next, Equation (3) compares the liquidity management of the $O B H C$-banks with the $M B H C$ banks. This time, the coefficients of $M B H C B$ and $M B H C B * C r i s i s$ illustrate the role of flows between affiliated banks in their liquidity management.

$\triangle Y_{i t}=T_{1 t}+B_{1 i}+\beta_{1}^{\prime} M B H C B_{i}+\beta_{2}^{\prime} M B H C B_{i} *$ Crisis $_{t}+\beta_{3}^{\prime} X_{i, t-1}+\beta_{4}^{\prime} X_{i, t-1} * C_{i s i s}+\varepsilon_{i t}$

Table III presents the results for Equation (3). Most of the control variables are found to be significant with their expected signs. The banks holding more illiquid assets decreased their lending faster in the crisis period and increased their liquid asset holdings. The ones holding higher core deposit and Tier 1 capital continued to lend in the crisis period. These findings are similar to the results of Correa, Goldberg and Rice (2014), which look at the liquidity management of international banks.

The table shows that flows between affiliates (bank/bank flows) made a significant impact only in the pre-crisis period. The banks that had access to funds from other affiliated banks in their group held less liquid assets in general, perhaps because they expected to resort to these 
funds when liquidity was needed. We can see that these results are in line with the theory, as discussed in Houston, James and Marcus (1997), which show that banks repeatedly use cash flows from their sister banks to deal with their liquidity problems.

\begin{tabular}{|c|c|c|c|c|c|c|}
\hline \multicolumn{7}{|c|}{ Table III: Bank/Bank Flows of MBHC-Banks versus OBHC-Banks } \\
\hline & $\Delta$ Credit & & $\Delta$ Loan & & $\Delta$ Liquid & \\
\hline & Coef. & Std. err & Coef. & Std. err & Coef. & Std. err \\
\hline $\mathrm{C}$ & $-0.072^{* * *}$ & 0.010 & $-0.003^{* * *}$ & 0.001 & $-0.005^{* * *}$ & 0.001 \\
\hline MBHC-bank & $-0.062^{* *}$ & 0.027 & $-0.010^{* * *}$ & 0.003 & $-0.009^{* * *}$ & 0.003 \\
\hline MBHC-bank ${ }^{*}$ Crisis & 0.011 & 0.012 & -0.001 & 0.002 & 0.003 & 0.002 \\
\hline Illiquid & -0.092 & 0.098 & $-0.049 * * *$ & 0.017 & $0.315^{* * *}$ & 0.021 \\
\hline Illiquid* Crisis & $-0.107^{* *}$ & 0.042 & $-0.016^{* * *}$ & 0.006 & $0.036^{* * *}$ & 0.007 \\
\hline Core & $-0.378^{* * *}$ & 0.096 & $-0.021^{*}$ & 0.012 & 0.012 & 0.011 \\
\hline Core* $^{*}$ Crisis & $0.218^{* * *}$ & 0.050 & $0.019^{* * *}$ & 0.005 & $-0.014^{* *}$ & 0.006 \\
\hline Tier1 & 0.144 & 0.500 & -0.002 & 0.091 & 0.108 & 0.069 \\
\hline Tier1* Crisis & $0.200^{* *}$ & 0.084 & 0.012 & 0.009 & -0.021 & 0.025 \\
\hline Commitment & $-0.420^{* * *}$ & 0.110 & $0.095^{* * *}$ & 0.015 & $-0.030^{* * *}$ & 0.010 \\
\hline Commitment* Crisis & 0.040 & 0.037 & 0.004 & 0.004 & 0.005 & 0.005 \\
\hline Logta & $-0.186^{* * *}$ & 0.039 & $-0.056^{* * *}$ & 0.005 & $-0.014^{* * *}$ & 0.005 \\
\hline Logta* Crisis & -0.007 & 0.006 & 0.000 & 0.001 & $-0.002^{* *}$ & 0.001 \\
\hline Obs & 8117 & & 8117 & & 7571 & \\
\hline $\mathrm{R}^{\wedge} 2$ & 0.09 & & 0.12 & & 0.15 & \\
\hline
\end{tabular}

On the other hand, the banks affiliated with $M B H C \mathrm{~s}$, in general, had a smaller credit and loan growth than the ones affiliated with $O B H C$ s. Frey and Kerl (2015) find similar results for the internal capital markets of multinational banks. They show that the reliance on internal flows caused affiliated banks to become more dependent on the group having a stable deposit and funding position. That over-reliance is seen as the cause of low credit growth. Table III also shows that bank/bank flows did not result in a significantly different behavior in the crisis period. This matches the findings of Cetorelli and Goldberg (2012). They discuss how flows dry out in the face of system-wide shocks. Banks dealing with their problems lose the ability to help other affiliated banks.

$M B H C$-Banks versus $M B H C$-Nonbanks: The Role of Bank/Non-bank Flows

Equation (4) is estimated for a sample that includes the $M B H C$-banks and the $M B H C$ nonbanks. Both the parent/bank flows and the bank/bank flows take place in the $M B H C$ banks and the $M B H C$-nonbanks. However, transfers between bank and non-bank affiliates (bank/non-bank flows) occur only in groups with non-bank affiliates. Therefore, $\beta_{1}$ and $\beta_{2}$ in equation (4) capture the role of these flows.

$\triangle Y_{i t}=T_{1 t}+B_{1 i}+\beta_{1}^{\prime} M B H C N B_{i}+\beta_{2}^{\prime} M B H C N B_{i} * \operatorname{Crisis}_{t}+\beta_{3}^{\prime} X_{i, t-1}+\beta_{4}^{\prime} X_{i, t-1} * C_{r i s i s}+\varepsilon_{i t}$

Table IV presents the results. Once again, the control variables have the signs that are in line with the previous literature and most of them are significant. Strikingly, differing from Table II and Table III, the bank/non-bank flows are found to be especially helpful in the crisis period. The banks that had access to non-bank flows were able to continue to make loans even in the crisis period. The liquid asset holdings were not significantly influenced by the bank/nonbank flows. However, the positive values of $\beta_{1}$ and $\beta_{2}$ suggest that these groups might have transferred funds from their non-bank entities to banks during the crisis period. This behavior is in line with Santioni et al (2019) which show that flows from cash-rich firms to cash-poor banks increase during the crisis periods. 


\begin{tabular}{|c|c|c|c|c|c|c|}
\hline & $\Delta$ Credit & & $\Delta$ Loan & & $\Delta$ Liquid & \\
\hline & Coef. & Std. err & Coef. & Std. err & Coef. & Std. err \\
\hline $\mathrm{C}$ & $-0.080^{* * *}$ & 0.009 & $-0.005^{* *}$ & 0.002 & -0.002 & 0.002 \\
\hline MBHC-Nonbank & -0.013 & 0.024 & -0.003 & 0.004 & 0.002 & 0.004 \\
\hline $\begin{array}{l}\text { MBHC- } \\
\text { Nonbank }{ }^{*} \text { Crisis }\end{array}$ & $0.033^{* * *}$ & 0.010 & $0.004^{* *}$ & 0.002 & 0.003 & 0.002 \\
\hline Illiquid & $-0.313^{* * *}$ & 0.091 & $-0.084^{* * *}$ & 0.020 & $0.285^{* * *}$ & 0.025 \\
\hline Illiquid* Crisis & $-0.080^{* *}$ & 0.032 & $-0.022^{* * *}$ & 0.005 & $0.035^{* * *}$ & 0.008 \\
\hline Core & -0.006 & 0.073 & -0.016 & 0.013 & 0.011 & 0.014 \\
\hline Core* $^{*}$ Crisis & $0.110^{* * *}$ & 0.041 & $0.015^{* * *}$ & 0.005 & $-0.013^{* *}$ & 0.007 \\
\hline Tier1 & -0.105 & 0.198 & 0.054 & 0.065 & $0.096^{*}$ & 0.056 \\
\hline Tier1*C & 0.033 & 0.057 & -0.009 & 0.008 & $0.035^{* *}$ & 0.017 \\
\hline Commitment & $-0.443^{* * *}$ & 0.083 & $0.078^{* * *}$ & 0.012 & $-0.037^{* * *}$ & 0.013 \\
\hline Commitment* Crisis & -0.035 & 0.026 & 0.000 & 0.004 & 0.007 & 0.006 \\
\hline Logta & $-0.074^{* * *}$ & 0.029 & $-0.041^{* * *}$ & 0.005 & -0.009 & 0.006 \\
\hline Logta* Crisis & 0.002 & 0.004 & 0.001 & 0.000 & $-0.002^{* * *}$ & 0.001 \\
\hline Obs & 9076 & & 9076 & & 8515 & \\
\hline $\mathrm{R}^{\wedge} 2$ & 0.08 & & 0.10 & & 0.14 & \\
\hline
\end{tabular}

The "Shiftability" theory that was pioneered by Moulton (1918) reaches a similar conclusion as well. One of the implications of Moulton's theory is that parent companies shift liquidity from institutions with a better cash position to those who need it during stressful periods. The findings in Table IV are also similar to Matvos and Seru (2014). They look at groups whose affiliates work in diverse sectors and show that the resource allocation within the internal capital markets provides a vital force countervailing the impact of a crisis.

\section{Robustness of the Results}

Another method that measures the treatment effect is propensity score analysis. The technique is particularly helpful in accounting for possible selection bias when it is infeasible to randomly assign participants to different regimes (See Lee and Little (2017)). The examples from this literature include assessing the effect of inflation targeting on fiscal discipline (Minea and Tapsoba (2014)), the impact of inflation targeting regime on the volatility of foreign portfolio investment in developing countries (Boughrara and Dridi (2017)) and the effects of small school size on mathematics achievement (Wyse, Keesler and Schneider (2008)).

Consider a trial that has two groups - a control and a treatment group - and an outcome. Assume that each subject has a pair of potential outcomes: $Y_{i}(0)$ and $Y_{i}(1)$ which are the outcomes under the control regime and the treatment regime respectively. Let $Z$ be an indicator variable denoting the treatment received ( $Z=0$ for control vs. $Z=1$ for treatment). Only one outcome, $Y_{i}\left(Y_{i}=Z_{i}\right)$, is observed for each subject since the same unit cannot simultaneously be in both the treatment and the control groups. Therefore, the treatment effect on a specific unit can't be measured directly.

Alternatively, the effect of a specific treatment on those receiving the treatment can be calculated. This is called the average treatment effect $(A T T)$. ATT is defined to be $E\left[Y_{i}(1)-\right.$ $\left.Y_{i}(0) \mid Z=1\right]$ (See Austin (2011)). To tackle the counterfactual problem, the method uses matched data. The matched units in the control group have similar probabilities of receiving the treatment to those of the corresponding units in the treatment group. Therefore, propensity score analysis allows one to estimate ATT (Imbens, 2004). 
This section presents the $A T T$ results for the banks that are matched with the nearest neighbor propensity scores ${ }^{6}$. Table V, VI and VII show the $A T T$ results for the same bank pairs that were analyzed in Table II, III and IV respectively. Each table has two panels: The upper panel represents the results for the full sample while the lower panel shows the results for the crisis period. In other words, the results in the upper panel would be referring to $\beta_{1}^{\prime}$ and the lower panel would be referring to $\beta_{2}^{\prime}$ in equations (2), (3) and (4). This helps us compare the results of the DD analysis of the previous section with the nearest matching analysis presented in this section.

\begin{tabular}{|c|c|c|c|c|}
\hline \multicolumn{5}{|c|}{$\begin{array}{l}\text { Table V: ATT Results for the Impact of Parent/Bank } \\
\text { Flows }\end{array}$} \\
\hline & Coef. & Std. Err. & $\mathrm{z}$ & $\#$ of Obs \\
\hline \multicolumn{5}{|c|}{ Full Sample } \\
\hline$\Delta$ Credit & 0.678 & 0.119 & $5.697^{* * *}$ & 19,639 \\
\hline$\Delta$ Loan & 0.093 & 0.044 & $2.113^{* *}$ & 19,639 \\
\hline$\Delta$ Liquid & 0.090 & 0.021 & $4.286^{* * *}$ & 18,129 \\
\hline \multicolumn{5}{|c|}{ Crisis Period } \\
\hline$\Delta$ Credit & -0.167 & 0.031 & $-5.430^{* * *}$ & 9,969 \\
\hline$\Delta$ Loan & -0.011 & 0.004 & $-2.640^{* *}$ & 9,969 \\
\hline$\Delta$ Liquid & 0.003 & 0.008 & 0.400 & 8,462 \\
\hline
\end{tabular}

Table $\mathrm{V}$ matches the stand-alone banks with the $O B H C$-banks. The $O B H C$-banks' credit, loan and liquid asset growths are found to be significantly different from the stand-alone banks in the top panel of the table. The $O B H C$-banks had a larger credit and loan portfolio expansion and they stayed more liquid as in Table II. The bank behavior in the crisis period is presented in the bottom panel. During the crisis period, the OBHC banks decreased their credits and loans more than the stand-alone banks, once again as in Table II. The signs of the variables are in line with the coefficients of $\beta_{1}^{\prime}$ and $\beta_{2}^{\prime}$ of Equation (2) that were given in Table II.

\begin{tabular}{|c|c|c|c|c|}
\hline & Coef. & Std. Err. & $\mathrm{z}$ & \# of Obs \\
\hline \multicolumn{5}{|c|}{ Full Sample } \\
\hline$\Delta$ Credit & -0.017 & 0.007 & $-2.470^{* *}$ & 5,826 \\
\hline$\Delta$ Loan & -0.002 & 0.001 & $-1.780^{*}$ & 5,826 \\
\hline$\Delta$ Liquid & -0.004 & 0.002 & $-1.700^{*}$ & 5,410 \\
\hline \multicolumn{5}{|c|}{ Crisis Period } \\
\hline$\Delta$ Credit & -0.014 & 0.009 & -1.560 & 2,875 \\
\hline$\Delta$ Loan & -0.001 & 0.001 & -1.170 & 2,875 \\
\hline$\Delta$ Liquid & 0.002 & 0.002 & 1.010 & 2,459 \\
\hline
\end{tabular}

Table VI presents the results for the $O B H C$-banks and the $M B H C$-banks. The top panel shows that the MBHC-banks were less liquid than the OBHC-banks in general and they had a smaller loan and credit growth in the entire period. On the other hand, there was no significant difference in the credit, loan and liquidity growths of the OBHC-banks and the MBHC-banks in the lower panel. This supports the findings of Table III, which suggest that bank/bank flows did not significantly influence banks' liquidity management in the crisis period.

\footnotetext{
${ }^{6}$ The nearest neighbor matching allows one to match the treated subject with an untreated subject whose propensity score is closest to the treated subject. See Austin (2011) for different methods of forming matched samples.
} 
Finally, Table VII presents the $A T T$ results for the $M B H C$-banks and the $M B H C$-nonbanks. The results in the top panel suggest that there was no significant difference in credit, loan and liquidity growth of the $M B H C$-nonbanks compared to the $M B H C$-banks. However, we see significantly faster credit and loan growths for the ones affiliated with $M B H C$-nonbanks during the crisis period.

\begin{tabular}{|c|c|c|c|c|}
\hline \multicolumn{5}{|c|}{$\begin{array}{l}\text { Table VII: ATT Results for the Impact of Bank/Nonbank } \\
\text { Flows }\end{array}$} \\
\hline & Coef. & Std. Err. & $\mathrm{z}$ & $\#$ of $\mathrm{Obs}$ \\
\hline \multicolumn{5}{|c|}{ Full Sample } \\
\hline$\Delta$ Credit & -0.003 & 0.005 & -0.580 & 8,881 \\
\hline$\Delta$ Loan & 0.000 & 0.001 & -0.520 & 8,881 \\
\hline$\Delta$ Liquid & 0.001 & 0.001 & 0.870 & 8,316 \\
\hline \multicolumn{5}{|c|}{ Crisis Period } \\
\hline$\Delta$ Credit & 0.024 & 0.011 & $2.181^{* *}$ & 4,142 \\
\hline$\Delta$ Loan & 0.004 & 0.002 & $2.116^{* *}$ & 4,142 \\
\hline$\Delta$ Liquid & 0.003 & 0.004 & 0.830 & 3,577 \\
\hline
\end{tabular}

Overall the results in this section support the findings of the DD analysis presented in Section 4. They illustrate that the impact of the internal flows is dependent on the time-crisis versus non-crisis - and type of the flows.

\section{Conclusion}

This paper examines the liquidity management of affiliated banks during the subprime mortgage crisis. Being affiliated with a bank holding company provides affiliates with different types of internal flows. These flows can be between parent/bank, bank/bank and bank/non-bank. Among these, only bank/non-bank flows are found to be helpful during the crisis period. The banks with access to non-bank flows made significantly more loans and credit during the crisis period.

The results of the paper have four important implications for policymakers. First, following the sub-prime mortgage crisis, complex financial institutions that are connected through ownership claims have been commonly criticized. The findings of this paper contribute to this discussion and suggest that $B H C$ affiliation does not automatically guarantee that affiliated banks will deal with liquidity shocks better. Being affiliated is found to be advantageous only under specific circumstances.

Second, the results suggest that crisis and non-crisis periods are different in terms of how beneficial internal funds are. If regulators' priority is to ensure uninterrupted credit flow during financial stresses, then they need to encourage $B H C$ s to have affiliates working in diverse industries. On the other hand, if the target of the policy is to achieve faster credit growth in non-crisis periods, then they should help parent/bank flows flourish.

Third, the findings of the paper have implications for global banks as well. The common perception in banking literature is that internal capital markets of global banks mitigate parent banks' local shocks. The results of the paper suggest that these generalizations might be misleading. To be able to evaluate the benefits of internal flows, policymakers need to look at the specific type of flows taking place among global affiliates and see whether groups are transferring funds between different industries.

Finally, the findings of the paper are especially important in reducing the impact of a potential banking crisis due to COVID-19. The crisis is expected to cause a significant deterioration in bank balance sheets due to loan losses and low interest rate margins, following the low interest rate policy of the Fed. The results of the paper suggest that regulators should encourage bank/non-bank flows as a response. Regulators should incentivize holding companies to acquire 
affiliates that work in different industries, especially the ones that are known to perform well during the COVID-19 crisis such as streaming companies, telecom services and online retailers.

\section{REFERENCES}

[1] Adams-Kane J., Caballero J. A. and Lim J. J. (2017) "Foreign Bank Behavior during Financial Crises" Journal of Money, Credit and Banking, Volume49, Issue2-3, March-April 2017: 351-392.

[2] Antoniades A. (2014) "Liquidity Risk and the Credit Crunch of 2007-2008: Evidence from Micro-Level Data on Mortgage Loan Applications" BIS Working Papers, No 473.

[3] Ashcraft, A. B, (2008) "Are bank holding companies a source of strength to their banking Subsidiaries", Journal of Money, Credit, and Banking 40: 273-294.

[4] Ashcraft, A. B., J. McAndrews, D. Skeie (2011) "Precautionary Reserves and the Interbank Market," Journal of Money, Credit and Banking, 43: 311-348.

[5] Austin P. C. (2011) "An Introduction to Propensity Score Methods for Reducing the Effects of Confounding in Observational Studies" Multivariate Behavior Research, 2011 May; 46(3): 399-424.

[6] Berrospide J. ( 2013) "Bank Liquidity Hoarding and the Financial Crisis: An Empirical Evaluation" Finance and Economics Discussion Series 2013-03, Board of Governors of the Federal Reserve System (U.S.).

[7] Bianchi J., and Bigio S. (2017) "Banks, Liquidity Management, and Monetary Policy" NBER Working Paper No. 20490.

[8] Boughrara A. and I. Dridi (2017) "Does Inflation Targeting Matter for Foreign Portfolio Investment: Evidence from Propensity Score Matching" Journal of Economic Development, Volume 42, Number 2, June 2017.

[9] Cai R. and Zhang M. (2017) "How Does Credit Risk Influence Liquidity Risk? Evidence from Ukrainian Banks," Visnyk of the National Bank of Ukraine, National Bank of Ukraine, 241: 21-32.

[10] Card, D., and Krueger A. B. (1994) "Minimum Wages and Employment: A Case Study of the Fast-food Industry in New Jersey and Pennsylvania." American Economic Review, 84(4): 772-793.

[11] Campello, M. (2002) "Internal capital markets in financial conglomerates: evidence from small bank responses to monetary policy", Journal of Finance 57: 2773-2805.

[12] Cetorelli N., and Goldberg L. S. (2012) "Liquidity management of U.S. global banks: Internal capital markets in the great recession" Journal of International Economics 88(2): 299-311.

[13] Chava S., and Purnanandam A. (2010) "The Effect of Banking Crisis on Bank-Dependent Borrowers" FDIC Center for Financial Research Working Paper No. 2010-09.

[14] Cornett M. M., McNutt J. J., Strahan J.E., Tehranian H. (2011), "Liquidity risk management and credit supply in the financial crisis", Journal of Financial Economics 101: 297-312.

[15] Correa R., Golberg L. S., and Rice T. (2014) "Liquidity Risk and U.S. Bank Lending at Home and Abroad", NBER Working Paper No. w20285.

[16] Frey R. and C. Kerl (2015) "Multinational banks in the crisis: Foreign affiliate lending as a mirror of funding pressure and competition on the internal capital market" Journal of Banking \& Finance 50: 52-68.

[17] Houston J., James C. and Marcus D. (1997) "Capital market frictions and the role of internal capital markets in banking". Journal of Financial Economics 46(2): 135-164.

[18] Houston J., and James C. (1998) "Do Bank Internal Capital Markets Promote Lending?" Journal of Banking and Finance 22(6-8): 899-918.

[19] Imbens G.W. (2004) "Nonparametric estimation of average treatment effects under exogeneity: A review." The Review of Economics and Statistics. 86: 4-29.

[20] King M., Massoud N. and Song K. (2013) "How Does Bank Trading Activity Affect Performance? An Investigation Before and After the Crisis" FDIC Working Paper.

[21] Lee J. and T. D. Little (2017) "A Practical Guide to Propensity Score Analysis for Applied Clinical Research" Behavior Research and Therapy 98: 76-90.

[22] Minea, A. and R. Tapsoba R. (2014) "Does inflation targeting improve fiscal discipline?," Journal of International Money and Finance 40(C): 185-203.

[23] Moulton, H.G (1918). Commercial banking and capital formation. The Journal of Political Economy 26(7): $32-38$.

[24] Matvos G., and Seru A. (2014) "Resource Allocation within Firms and Financial Market Dislocation: Evidence from Diversified Conglomerates" Review of Financial Studies 27(4): 1143-1189.

[25] Rauch C. (2010) "International Banking in the New Era: Post-crisis Challenges and Opportunities" Publication Date: Volume: 11, Book Series: IFR, Emerald Insight.

[26] Santioni R., Schiantarelli F. and Philip E. Strahan (2017) "Internal Capital Markets in Times of Crisis: The Benefit of Group Affiliation in Italy," Review of Finance.

[27] Stein, Jeremy C (1997) "Internal Capital Markets and the Competition for Corporate Resources," Journal of Finance 52(1): 111-133.

[28] Wooldridge J. M. (2010) "Econometric Analysis of Cross Section and Panel Data", The MIT Press, second edition. 
[29] Wyse A.E., Keesler V., and B. Schneider (2008) Assessing the effects of small school size on mathematics achievement: A propensity score-matching approach. Teachers College Record 110: 1879-1900. 


\section{Appendix A: Data Definitions}

The variables in Figure 1 are aggregated values. Whereas, the variables in Table Ia, Ib, II, III, IV, V, VI, and VII are at bank-level and normalized by total bank assets.

The definitions of the variables are listed below:

Liquid: Noninterest-bearing cash balances + interest-bearing cash balances + non-MBS and non-ABS held-to-maturity (HTM) securities+ non-MBS and non-ABS available-for-sale (AFS) securities+ Fed funds sold securities purchased under agreements to resell.

Loan: Total bank loans.

Illiquid: Loans and leases net of unearned income and allowances + MBS and ABS HTM securities + MBS and ABS AFS securities.

Core: Deposits under $\$ 100,000+$ all transactions deposits.

Tier1: Tier 1 bank capital.

Commitment: Total loan commitments,

Credit: Total loans on the balance sheet + undrawn loan commitments off the balance sheet

Crisis: A dummy variable that takes the value of 1 between the last quarter of 2007 and the middle of 2009 and 0 otherwise.

OBHC-bank: A dummy variable that takes the value of 1 when the bank is affiliated with a group that includes only the bank itself and the parent.

MBHC-Bank: A dummy variable that takes the value of 1 when the bank is affiliated with a group that includes more than one bank and no non-bank affiliates.

$M B H C N B$ : A dummy variable that takes the value of 1 when the bank is affiliated with a group that includes more than one bank and non-bank affiliates. 


\section{Appendix B: Bank Classification}

The types of internal flows taking place in internal capital markets depends on two characteristics of the BHC: the number of affiliates and the type of affiliates. If the BHC includes only one affiliated bank, then the internal flows can take place only between the parent and the affiliated bank. These flows are called "parent/bank flows". Whereas, if the group includes a parent and more than one affiliated banks, then the flows can take place among individual banks as well as the parent and each of the affiliates. The flows taking place among individual banks are called "bank/bank flows". Similarly, if the group includes more than one affiliate, one of which is a non-bank company, then flows can also take place between the bank and the non-bank affiliate. These flows between the banks and the non-bank entities are called "bank/non-bank flows".

Based on the fact that internal flows depend on the number and the types of affiliates in the group, the banks in the sample are divided into five groups as shown in Figure 2. First, the affiliated banks are separated from the stand-alone banks. The difference between the two is that there is no internal capital markets in the stand-alone banks, whereas there are flows that the affiliated banks can participate in their BHC.

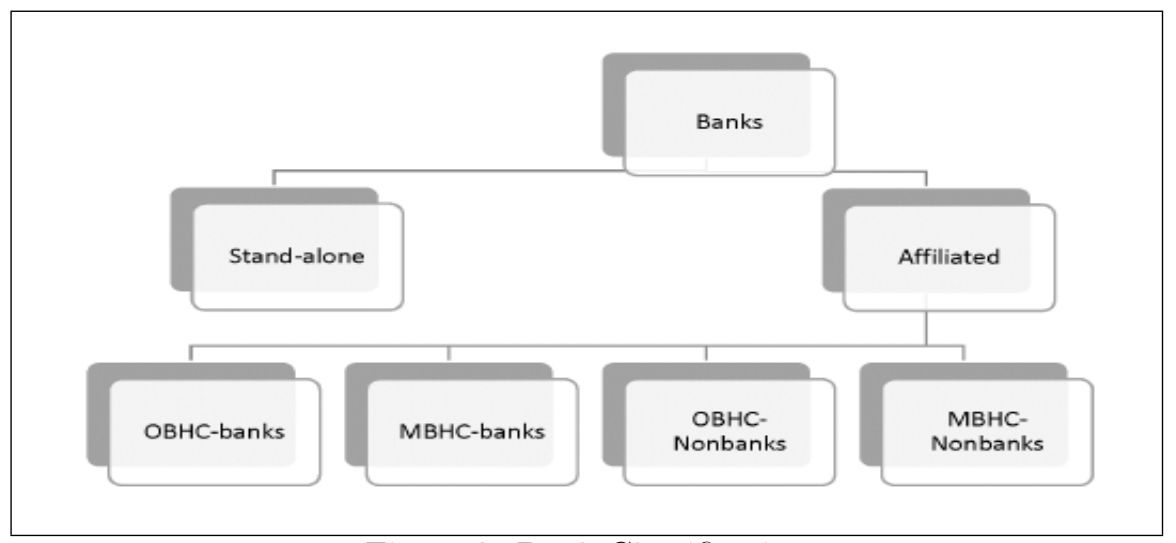

Figure 2: Bank Classification

Second, the affiliated banks are divided into four groups based on the number of affiliates and the type of affiliates. An OBHC-bank is a bank that is affiliated with a group that includes only the bank itself and the parent. Only parent/bank flows can be observed here. Therefore, the OBHC-banks differ from the stand-alone banks with the existence of only one type of flow (Figure 3a).

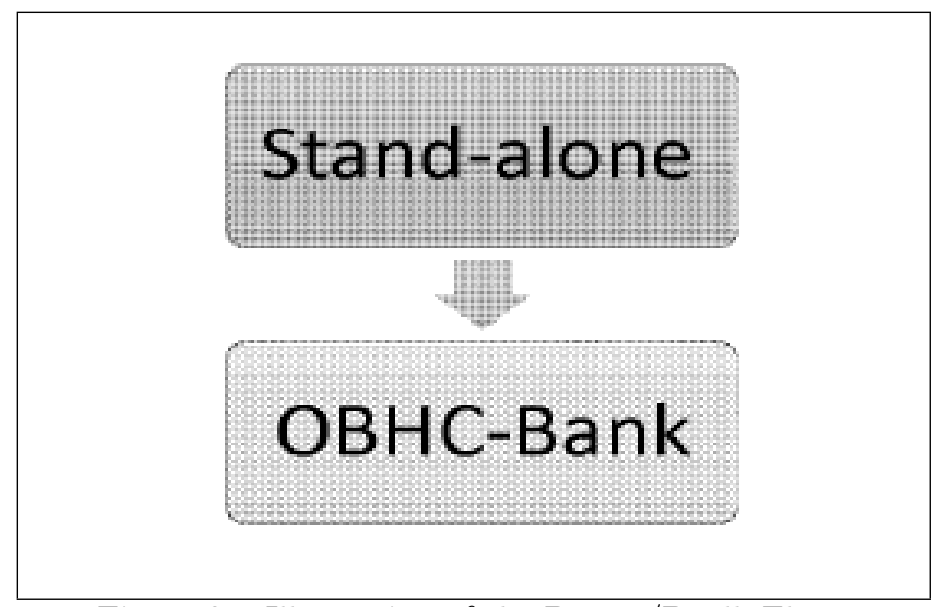

Figure 3a: Illustration of the Parent/Banlk Flows 
If two or more banks are affiliated with the same BHC (and the group does not hold any nonbank subsidiaries), then these banks are called MBHC-banks. Two types of flows are expected to take place in MBHCs: First, between the parent and each one of the affiliated banks and second among the affiliated banks. The bank/bank flows takes place only in the MBHC-banks. Figure 3b illustrates this.

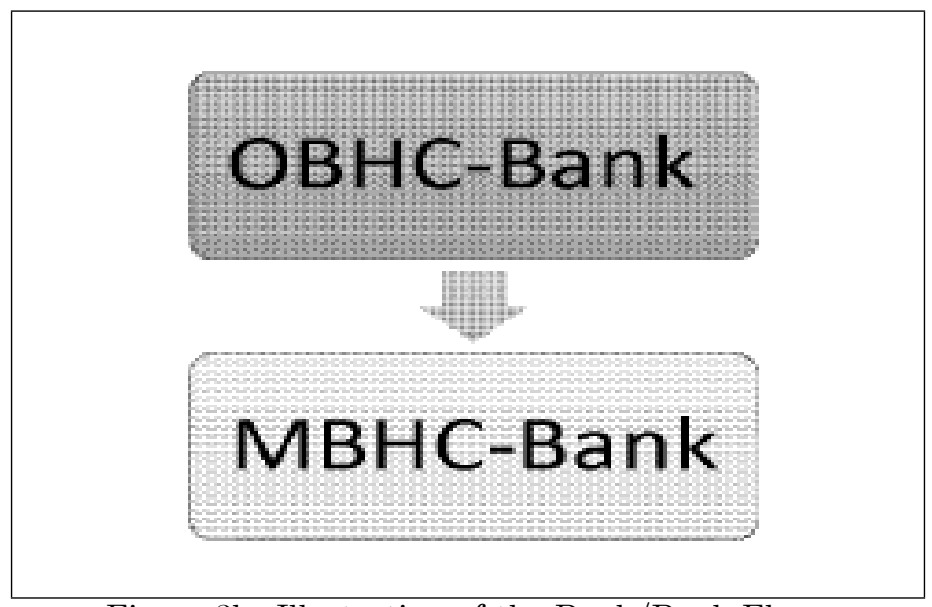

Figure 3b: Illustration of the Bank/Bank Flows

BHCs may hold non-bank affiliates as well. The banks affiliated with groups that own non-bank affiliates are called MBHC-Nonbanks in Figure 2. This time the existence of nonbank affiliates would introduce one additional type of flow compared to the baseline group: Bank/non-bank flows (Figure 3c).

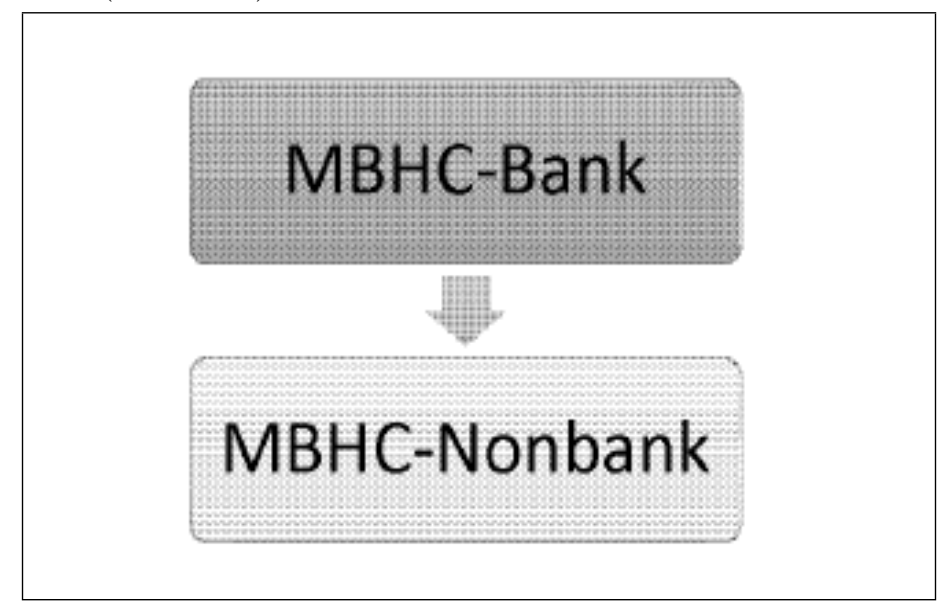

Figure 3c: Illustration of the Bank/Nonbank Flows

The List of Figures

Figure 1: Graphical Representations of the Liquidity Management Indicators

Figure 2: Bank Classification

Figure 3a: Illustration of Parent/Bank Flows

Figure 3b: Illustration of Bank/Bank Flows

Figure 3c: Illustration of Bank/Nonbank Flows 